\title{
PENERAPAN TEKNIK RELAKSASI DISELA PENGERJAAN TUGAS OLEH MAHASISWA DI MASA COVID-19
}

\author{
APPLICATION OF RELAXTION TECHNIQUES IN BETWEEN \\ STUDENT WORK DURING THE COVID-19 PANDEMIC
}

\section{Putri Raisha Jaya}

S1 Psikologi Fakultas Kedokteran Universitas Lambung Mangkurat

2010914320019@mhs.ulm.ac.id

\begin{abstract}
ABSTRAK
Pandemi civid-19 pada masa sekarang menyebabkan semua serba onlen termasuk pengerjaan tugas yang membuat para dosen mengira bahwasanya di rumah saja hanya rebahan dan tidak melakukan aktivitas yang membuat banyaknya tugas yang di berikan oleh mahasiswa, hal ini menyebabkan mahasiswa banyak mengalami stress yang tidak terkendali, emosi yang tidak stabil, tekanan fikiran, perubahan perilaku mahasiswa. Hal ini banyak sekali terjadi di masa pandemic covid-19 ini. Yang kemudian diperlukannya tips - tips untuk menjadi penerapan yang bisa di lakukan di masa pandemic covid-19 yang mengharuskan mahasiswa beraktivitas di rumah saja. Beberapa tips yang bisa dilakukan mahasiswa selama di rumah saja seperti relaksasi nafas, relaksasi imagery, mendengarkan musik, serta rehat sejenak untuk mengerjakan tugas dan kemudian dilanjutkan kembali, hal ini bisa menjadi jalan keluar bagi mahasiswa yang sedang mengalami tekanan, jenuh dan stress dikala pengerjaan tugas dan terbukti efektif.
\end{abstract}

Kata Kunci : mahasiswa, relaksasi, pandemi covid-19

\begin{abstract}
The Civid-19 pandemic at the present time causes everything to be online, including work on assignments that make lecturers think that at home, they are just lying down and not doing activities that cause many assignments given by students, this causes students to experience a lot of uncontrollable stress, unstable emotions, stress, changes in student behavior. This happened a lot during the Covid-19 pandemic. What then needs tips to become an application that can be done during the Covid-19 pandemic, which requires students to do activities at home. Some tips that students can do while at home such as breathing relaxation, imagery relaxation, listening to music, and taking a break to do assignments and then continuing again, this can be a way out for students who are experiencing pressure, boredom and stress while doing assignments and proven effective.
\end{abstract}


2 | Jurnal Edukasi, Volume 1, nomor 1, November 2020

Keywords ; Collage Student, relaxtion, the covid-19 pandemic 



\section{PENDAHULUAN}

Tahapan tertinggi dalam pendidikan yaistu menjadi seorang mahasiswa. Mahasiswa di tuntut untuk dapat belajar dan mengerjakan tugas dengan mandiri. Lailina \& Agustin (2017) mengemukakan semestinya mahasiswa harus mau melibatkan dirinya secara penuh terhadap tugasya sebagai mahasiswa dan bertanggung jawab terhadap tugas yang diberikan oleh dosen [1]. Rasa tanggung jawab terhadap tugas tersebut yang membuat mahasiswa selalu terfikirkan oleh tugas, apalagi ketika tugas yang deadlinenya sebentar, hal itu akan menjadi beban fikiran yang menyebabkan seorang mahasiswa menjadi stress dan tertekan mentalnya juga fikirannya yang bisa berakibat fatal bagi jasmani dan rohaninya.

Gemilang (2013:153) memberi pengertian bahwa relaksasi merupakan satu teknik yang dapat di gunakan semua orang untuk menciptakan mekanisme bati dalam diri seseorang dalam mengendalikan stress dan emosi yang di milikinya, mempermudah seseorang mengontrol diri, menyelamatkan jiwa dan membersihkan kesehatan dan kecantikan tubuh[2]. Hal ini yang bisa menjadi jalan keluar seorang mahasiswa untuk meredupkan stress nya dan tekakan pikirannya, teknik relaksasi ini juga bisa meningkatkan daya kerja untuk mengerjakan tugas meningkat dan membuat fikiran relax dan bisa berfikit kembali.

Di masa pandemi covid-19 ini semua serba online termasuk tugas pun juga termasuk online, yang membuat para mahasiswa di haruskan sering sering berhadapan dengan laptop maupun handphone, tidak hanya mahasiswa bahwan seluruh pelajar pun seperti itu, namun yang menjadi fikiran disini adalah susahnya untuk berkonsultasi ataupun berkomunikasi dengan dosen dikarenakan jaringan yang bisa saja naik turun, kuota yang sangat boros, dosen yang sangat sulit di hubungu yang bisa saja membalas sehari setelah kita kirimkan pesan kepada beliau. Dan apalagi di masa pandemic ini orang di haruskan untuk di rumah yang membuat mahasiswa susah untuk mencari suasana yang bisa menyegarkan fikiran yang membuat rasanya kepala ingin pecah dikarenakan tugas yang belum selesai. Relaksasi dapat di lakukan oleh mahasiswa yang sedang pusing dengan tugas mereka yang sedang menumpuk untuk membuar fikiraan terbuka juga bisa menjadi leluasa untuk berfikir, banyak sekali tips - tips relaksasi yang 
dapat di lakukan di rumah dan juga bisa menyegarkan fikiran dikala stress memikirkan tugas.

\section{METODE PENELITIAN}

Pada penelitian ini metode yang di gunuakan adalah metode literature yang dimana metode ini berdasarkan pada artikel dan jurnal juga sumber daftar pustaka yang sudah dan telah diterbitkan melalui media internet juga elektronik.

Melalui artikel, jurnal dan sumber - sumber pustaka yang di dapatkan inilah sehingga penulis menemukan referensi dari pemikiran banyaknya orang juga ahli maupun ilmuan, hasil penelitian juga perbandingan para ahli terhadap pembahasan yang di angkat oleh penulis. Sumber -sumber ini di dapatkan tentu saja melalui media online seperti internet maupun media elektronik yang membuat penulis bisa mengembangkan pemikirannya untuk menyelesaikan artikel ini. Ersis Writing Theory (EWT) mengatakan tulislah apa yang ada di dirimu, pikiranmu dan atau yang disenangi[3].

Dalam penulisan artikel ini saya sebagai penulis membahas tentang pentingnya tugas yang menjadi tanggung jawab mahasiswa, kemudian bagaimana kondisi mahasiswa yang di pengaruhi oleh tugas - tugasnya yang terdiri dari dampak yang di timbulkan ketika mahasiswa sedang tertekan atas tugasnya. Dalam artikel ini saya juga akan membahas pentingnya penerapan teknik relaksasi yang menjadi jalan keluar untuk mahasiswa yang tertekan ataupun stress dengan tugasnya di masa pandemi covid-19 yang di mana orang - orang banyak menghabiskan waktu di rumah saja di karenakan wabah yang sedang meradang ini.

Tentunya saya juga membahas tips -tips apa saja yang bisa di lakukan di rumah selama masa covid-19 ini yang bisa bermanfaat bagi orang dan bis membantu mahasiswa mencari relaksasi untuk dirinya sendiri dan mencegah dampak terburuk yang akan di dapatkan dari pengaruh stress dan tekana yang menjadi beban pikiran mahasiswa.

\section{HASIL DAN PEMBAHASAN}

Mustari (2011:2) menyatakan bahwa tanggung jawab adalah sikap dan perilaku seseorang untuk melaksanakan tugas dan kewajiban yang seharusnya dia lakukan terhadap diri sendiri, masyarakat, lingkungan ( alam, sosial, dan budaya), negara dan tuhan[4]. Tugas sendiri merupakan kewajiban yang harus di selesaikan bagi seluruh mahasiswa karna itu 
merupakan tanggung jawab masing masing individu, rasa tanggung jawab sendiri akan muncul atas kesadaran diri sendiri, ketika seorang mahasiswa memiliki rasa tanggung jawab atas tugasnya maka ia dapat menghargai dosen yang telah memberikannya tugas dan dapat meningkatkan pemahaman tentang pengetahuan atas tugas yang diberikan tersebut.

Menurut moore (dalam Rumiani, 2006), stressor mahasiswa dapat berupa keuangan, beban tugas, ujian dan masalah interaksi dengan teman - temannya. Stressor yang di alami oleh mahasiswa meliputi tugas, jadwal kegiatan padat, ujian, managemen waktu dan standar nilaii yang di tetapkan[5]. Dampak tekanan mahasiswa dalam tugas sering terjadi yang mana siswa mengalami stress dan tekanan mental dan fikiran atas banyaknya tugas yang deadlinenya berdekatan, kepuasan juga keinginan untuk mendapatkan hasil yang baik agar bisa melampaui nilai yang di tetapkan pun bisa menjadi penyebab mahasiswa mengalami tekanan fikiran juga strees. Apalagi di masa covid-19 ini yang di mana orang - orang di himbau untuk melakukan aktivitas di rumah saja yang membuat mahasiswa terbatas untuk keluar rumah walaupun hanya untuk mencari udara segar untuk menenangkan fikiran mereka karna udara di luar rumah saat pandemi ini sangatlah berbahaya dan tercemari virus, jadilah semakin sakit kepala karna memikirkan beban fikiran yang menumpuk. Dampak buruk terburuk yang bisa terjadi adalah penggunaan narkoba dan narkotika untuk melampiaskan beban yang memenuhi fikiran tersebut.

Hardjana (1994) menyatakan bahwasanya stress dapat menyebabkan ganggguan fikiran, emosi, dan perilaku[6]. Dampak lainnya yang dipengaruhi oleh tekanan tugas adalah emosi yang tidak stabil dan tidak kondisional, pola makan yang tidak teratur, juga pola tidur yang tidak teraktur akibat tugas yang belum selesai, Perilaku pun bisa berubah karna dipengaruhi emosi yang tidak stabil. Kecemasa dan tekanan yang meningkat ketika sejumlah tugas harus di selesaikan menjadi sumber stress mahasiswa[7].

Relaksasi disela pengerjaan tugas sangatlah penting bagi mahasiswa karna ketika mahasiswa sedang pusing memikirkan tugas yang belum selesai sedangkan tugas lain masih banyak diperlukan relaksasi sejenak untuk merelaksasikan fikiran yang bisa membuat mahasiswa berfikir lebih leluasa dan bisa mengerjakan 
tugas kembali. Banyak cara dan tips tips agar mahasiswa dapat merelaksasikan fikiran juga otot yang tegang akibat terlalu lama duduk di depan laptop, apalagi di masa kovid ini bisa saja kita lakukan di rumah bahkan bisa dilakukan sambil rebahan mauoun duduk santai.

Langkah pertama untuk relaksasi yaitu relaksasi nafas. Relaksasi nafas merupakan relaksasi dengan cara menarik nafas kemudian menghembuskannya kembali. cara relaksasi nafas yang benar adalah nafas perut[8]. Hal ini bisa di lakukan sambil rebahan di kasur juga sambil senderan di kursi, kemudian mahasiswa bisa melanjutkan kembali tugasnya.

Langkah selanjutnya adalah relaksasi imagery, sama seperti teknik pernafasan bedanya adalah relaksasi imagery dilakukan dengan membayangkan sesuatu yang dapat menenangkan fikiran seorang mahasiswa[8]. Hal ini bisa di terapkan di masa pandemi covid-19 sekarang ini.

Selanjutnya adalah mendengarkan musik yaitu dimana kita mengerjakan tugas bisa sambil mendengarkan music, music sendiri bisa membuat tenang pikiran kita. Pada hormone tiroksinyang tinggi akan menyebabkan mahasiswa mudah lelah, mudah cemas, mudah tegang, dan susah tidur sehingga keadaan mendengarkan music yang penuh perasaan tenang dan damai akan menimbulkan dampak psikis yang lebih tenang dan relaks (Safaria, \& Saputa, 2009; Bartlet, 2005; Fukui, Arai, \& Toyoshima, 2010)[9]. Hal ini membuktikan bahwa musik dapar membantu rileksasi pada mahasiswa dikala stres dan hal ini pun sangat efektif untuk melakukannya di rumah pada masa pandemi covid-29 ini.

selanjutnya adalah mengerjakan tugas sambil makan cemilan ataupun minuman rasa yang sudah banyak di jual di jalanan, di masa yang sudah maju ini kita bisa memesan atau mendapatkan camilan dan minuman rasa tersebut lewat aplikasi online yang sudah tersedia, sehingga bisa memudahkan kita mendapatkannya. Kemudian melanjutkan kembali tugas hingga selesai.

Rehat sejenak juga bisa menjadi tips untuk meredakan stress dan tekanan yang membebani pikiran mahasiswa ketika mengerjakan tugas, rehar sejenak yaitu berhenti mengerjakan tugas sebentar dan melakuan rileksasi seperti rebahan untuk menenangkan otot yang tegang akobat duduk terlalu lama di kursi, dan 
mengistirahatkan mata yang sudah berada di depan laptop dengan waktu yang lama, kemudian lanjur jika serasa sudah cukup untuk melakukan rileksasi dan kemudian melanjutkan kembali untuk mengerjakan tugas. Hal ini mungkin saja membuat mahasiswa rentas malas untuk mengerjakan kembali tugasnya, namun oada dasarnya hal ini dapat membantu untuk merelaksasikan tuubuh mahasiswa yang tegang dan lelah akibat duduk terlalu lama di kursi.

Pada dasarnya ketika kita sedang mengerjakan tugas, jika ingin cepat selesai dan tidak menumpuk adalah dengan mengerjakannya jauh hari sebelum deadline dan jangan menunda - nundanya, seringkali apalagi di masa covid-19 ini yang menyebabkan mahasiswa lebih banyak beraktivitas di rumah saja membuat mahasiswa jadi malas bergerak dan menjadi kaum rebahan. Sehingga tugas yang seharusnya dikerjakan saat itu malah di tunda - tunda pengerjaannya yang membuat tugas itu menumpuk dan membuat mahasiswa sendiri stres dan menjadi beban pikiran mahasiswa. Saya mengutip kata - kata oleh Ersis Writing Theory (EWT) menyebutkan bahwa : Berdamai dengan diri, menerima dan mengerjakan tugas dengan lapang dada sembari bersembah diri[10]. Yang bisa menjadi motivasi bagi mahasiswa yang menjalani perkuliahan di masa pandemi covid-19 ini. Dan memanagement waktu agar bisa menyesuaikan diri dengan masa perkuliahan di era covid-19.

\section{KESIMPULAN}

Tugas sendiri merupakan kewajiban yang harus di selesaikan bagi seluruh mahasiswa karna itu merupakan tanggung jawab masing masing individu, rasa tanggung jawab sendiri akan muncul atas kesadaran diri sendiri, ketika seorang mahasiswa memiliki rasa tanggung jawab atas tugasnya maka ia dapat menghargai dosen yang telah memberikannya tugas dan dapat meningkatkan pemahaman tentang pengetahuan atas tugas yang diberikan tersebut.

Dampak tekanan mahasiswa dalam tugas sering terjadi yang mana siswa mengalami stress dan tekanan mental dan fikiran atas banyaknya tugas yang deadlinenya berdekatan, kepuasan juga keinginan untuk mendapatkan hasil yang baik agar bisa melampaui nilai yang di tetapkan pun bisa menjadi penyebab mahasiswa mengalami tekanan fikiran juga strees. 
Apalagi di masa covid-19 ini yang di mana orang - orang di himbau untuk melakukan aktivitas di rumah saja yang membuat mahasiswa terbatas untuk keluar rumah walaupun hanya untuk mencari udara segar untuk menenangkan fikiran mereka karna udara di luar rumah saat pandemi ini sangatlah berbahaya dan tercemari virus, jadilah semakin sakit kepala karna memikirkan beban fikiran yang menumpuk.

Dampak lainnya yang dipengaruhi oleh tekanan tugas adalah emosi yang tidak stabil dan tidak kondisional, pola makan yang tidak teratur, juga pola tidur yang tidak teraktur akibat tugas yang belum selesai, Perilaku pun bisa berubah karna dipengaruhi emosi yang tidak stabil.

Relaksasi disela pengerjaan tugas sangatlah penting bagi mahasiswa karna ketika mahasiswa sedang pusing memikirkan tugas yang belum selesai sedangkan tugas lain masih banyak diperlukan relaksasi sejenak untuk merelaksasikan fikiran yang bisa membuat mahasiswa berfikir lebih leluasa dan bisa mengerjakan tugas kembali.
Rehat sejenak juga bisa menjadi tips untuk meredakan stress dan tekanan yang membebani pikiran mahasiswa ketika mengerjakan tugas, rehar sejenak yaitu berhenti mengerjakan tugas sebentar dan melakuan rileksasi seperti rebahan untuk menenangkan otot yang tegang akobat duduk terlalu lama di kursi, dan mengistirahatkan mata yang sudah berada di depan laptop dengan waktu yang lama, kemudian lanjur jika serasa sudah cukup untuk melakukan rileksasi dan kemudian melanjutkan kembali untuk mengerjakan tugas.

\section{DAFTAR PUSTAKA}

[1]Amini, M., Mayangsari, M. D., \& Zwagery, R. V. (2020). Hubungan antara Kemandirian Belajar dengan Komitmen Tugas pada Mahasiswa Program Studi Psikologi. Jurnal Kognisia: Jurnal Mahasiswa Psikologi Online, 2(2), 149-152.

[2]Abbas, E. W. (2020). Ersis Writing Theory: Cara Mudah Menulis.

[3]EKA KHUSUMAWATI, Z. U. N. I. (2014). Penerapan Kombinasi antara Teknik Relaksasi dan Self-Instruction untuk Mengurangi Kejenuhan Belajar Siswa Kelas XI IPA 2 SMA Negeri 22 Surabaya. Jurnal BK UNESA, 5(1).

[4]Heriansyah, M., \& Kurniawan, D. (2017). Bimbingan Kelompok dengan Teknik Self Management untuk Meningkatkan Tanggung Jawab Belajar Mahasiswa. Jurnal Penelitian Pendidikan Indonesia, 2(2). 
8 | Jurnal Edukasi, Volume 1, nomor 1, November 2020

[5]Mulya, H. A., \& Indrawati, E. S. (2017). Hubungan antara motivasi berprestasi dengan stres akademik pada mahasiswa tingkat pertama Fakultas Psikologi Universitas Diponegoro Semarang. Empati, 5(2), 296-302.

[6]Sutjiato, M. (2015). Hubungan faktor internal dan eksternal dengan tingkat stress pada mahasiswa Fakultas Kedokteran Universitas Sam Ratulangi Manado. JIKMU, 5(1).

[7]Agista, I. (2011). Penanganan Kasus Stres dalam menghadapi Aktivitas Kuliah melalui Pendekatan Konseling Behavioristik dengan Teknik Pengelolaan Diri pada Mahasiswa Jurusan Seni Rupa FBS UNNES Tahun Ajaran 2010/2011 (Doctoral dissertation, Universitas Negeri Semarang).

[8]SURYATNA, A. (2019). PERANCANGAN BUKU ILUSTRASI: TIPS UNTUK MENGHADAPI DAN MENGATASI STRES KULIAH (Doctoral dissertation, UNIKA SOEGIJAPRANATA SEMARANG).

[9]Rosanty, R. (2014). Pengaruh musik mozart dalam mengurangi stres pada mahasiswa yang sedang skripsi. Journal of Educational, Health and Community Psychology, 3(2), 24817.

[10]Abbas, E. W., \& Erlyani, N. (2020). Menulis di Kala Badai Covid19. 